\title{
Contested Townscapes: The Walled City as World Heritage
}

\section{Oliver Creighton}

\section{Abstract}

Walled towns and cities feature prominently on the list of UNESCO World Heritage Sites. But while a fundamental guiding principle of the WHS list is that properties are designated for the benefit of all, these historic walled communities can be conceptualised as a particularly 'dissonant' form of heritage where the past is contested or disputed in the present. Many such places have violent histories and have changed political or national allegiance in the past. Moreover, city walls, while outwardly embracing populations, also inevitably serve to exclude or marginalise other social groups. The identities of walled heritage cities are multi-layered and far from static, being susceptible to re-invention. Tensions and contradictions are also apparent in the fact that heritage agencies work in national contexts on the management of sites that are designated as an international resource, and the agendas of these organisations can mean that certain periodsor interpretations of the past are prioritised above others. All these factors present considerable challenges to those responsible for conserving and researching heritage sites that are simultaneously living communities. Against this background, the practicalities and politics of designating and delineating historic walled communities as World Heritage Sites are reviewed, as are strategies for managing the archaeological resource. The paper draws on examples of walled communities inscribed as UNESCO World Heritage Sites, with a particular emphasis on Europe, North Africa and the Middle East. Key sites include Acre (Israel), Ávila (Spain), Carcassonne (France), Conwy (United Kingdom), Dubrovnik (Croatia) and Jerusalem.

\section{Keywords}

Walled town; dissonant heritage; UNESCO World Heritage Site

\section{Introduction}

Walled urban settlements represent a quintessential form of World Heritage Site (WHS): 'gem towns' such as Carcassonne, Toledo and Valetta feature prominently on a UNESCO list that is both dominated by 'tangible' heritage and displays an undeniable Eurocentric bias. This paper examines critically the concept of 'dissonant heritage' (that is tension and discord between populations and their heritage: Tunbridge and Ashworth 1996), using historic walled towns and cities on the WHS list as a case study. While a fundamental guiding principle of the UNESCO list is that sites are designated for the benefit of 'all' (although not interpreted literally), it is argued here 
that the particular physical and social characteristics of historic walled urban communities create unusually high potential for the past to become contested or disputed in the present in some way. Contestation can operate at various scales and between different interest groups - including host communities, tourists, archaeologists and heritage agencies - and creates ethical dilemmas that compound the considerable practical challenges of conserving, preserving and researching the multi-layered pasts of these places.

A growing body of literature is addressing the histories and archaeologies of historic walled communities, whether focused on particular countries (for the UK, see Creighton and Higham 2005), regions (for North Africa, see Slyomovics 2001), continents (for Europe, see Perbellini 2000), or the phenomenon viewed globally (Tracy 2000). The legacies for present populations and other stakeholders of having to engage with a walled heritage than can be divisive and contentious remain relatively little studied, however, and under-acknowledged in archaeological discourse (see Bruce and Creighton 2006). While case studies of the disputed heritages of individual walled WHS cities have been developed (e.g. for Quebec, see Evans 2002; for Jerusalem, Abu El-Haj 2002), this paper adopts a more broadly based and comparative approach that attempts to identify wider issues and draw out general lessons. Addressing an area of interface between archaeology and heritage studies, it also extends beyond the built heritage of city walls and the settlements they encircle to acknowledge more intangible dimensions to this heritage. Urban walls are also mental constructs and critical components to the multi-layered self-images of communities, and it is perfectly legitimate to consider some urban communities as psychologically walled even where the physical fabric of defences has been removed or compromised in some way.

\section{Walled Heritage as World Heritage}

The phenomenon of the walled heritage city is examined here with a particular focus on Europe, the Middle East and North Africa (Figure 1; for representative plans see Figure 2). It is also restricted to historic urban sites inscribed as UNESCO World Heritage Sites that persist as living communities. Globally, this distinctive group of sites - to which the most recent addition is the Ethiopian fortified desert city of Harar Jugol (2006) - comprises well over 100 of the 644 cultural properties on the UNESCO list. Moreover, for countries such as Albania, Morocco and Yemen, walled towns represent the only category of WHS site represented. Crucially, the monumentality of upstanding remains a stronger reason for the inclusion of a site on the list than archaeological potential or significance. It is difficult to envisage earthwork complexes gaining WHS status, for instance, while the list remains site-centric at the expense of wider landscapes and, 
significantly for the subject of this paper, the hinterlands and settings of settlements and monuments.

In terms of the criteria under which these walled towns are judged as having 'outstanding universal value', all have in common inscription under UNESCO's criteria (iv), meaning that each constitutes "an outstanding example of a type of building, architectural or technological ensemble or landscape which illustrates (a) significant stage(s) in human history" (UNESCO 2005: 20). Variations are apparent, however. A minority of sites has also been inscribed partly because of their 'intangible' heritage (and meet criteria (i): 'human creative genius', as with Valetta's link to the Order of the Knights of St John of Jerusalem). Other sites additionally meet criteria (iii) (and 'exhibit an important interchange of human values', where the walled ensemble demonstrate diverse cultural influences: e.g. Graz; L'viv) and/or (iv) ('exceptional testimony to a cultural tradition', where the town embodies a single social, ethnic or religious influence influence: e.g. Ávila; Shibam). Finally, the physical fabric of walls varies considerably in its importance to the inclusion of sites, from cases where walled heritage is integral to WHS status (e.g. 'Historic Walled Town of Cuenca', 'Old City of Jerusalem and its Walls') to places where walls are vestigial and incidental to inscription (e.g. Bath, Edinburgh, Salzburg).

If heritage is, in essence, a 'personal affair' (Tunbridge and Ashworth 1996: 70), then potential for dissonance is arguably greater in the case of the WHS given the variety of scales at which relationships between stakeholders and heritage operate, ranging from the local to the global. A critical point here is an underlying incongruity at the very core of the WHS inscription process. While properties are ostensibly inscribed for the benefit of humanity (regardless of where they are situated), they are nominated for inclusion not by UNESCO, but by the governments of sponsoring states, and it is consequently quite clear that the evolving WHS list is used as a tool for shaping national identities (see van der Aa 2005). Also potentially contestable is the principle that it is the governments currently controlling territories within which properties lie that have the dominant claim with regard to nomination, despite the fluid nature of state-making in the late twentieth and early twenty-first centuries. The exemplar is Jerusalem - the archetypal 'contested city' (Klein 2001). The city's political status being uncertain since 1967, Jerusalem is unique on the UNESCO list in not being listed under a 'host' country; it was inscribed along with its walls in 1981 following a (much disputed) proposal from Jordan, despite lying beyond the borders of the sponsoring state (UNESCO 1981: 6-15).

The processes through which walled towns and cities have been added to the UNESCO list also betray changing sensibilities regarding the perception and definition of 'World Heritage'. Many were 
designated relatively early in the history ofthe list and, in Europe at least, they have fallen out of favour as a 'brand' of WHS. The case of Carcassonne (Figure 3) is instructive. The Cité Médiéval was denied inscription as a WHS in 1985 not only as European walled towns already featured heavily on the list, but because Viollet-le-Duc's internationally famous restorations of the nineteenth century were judged to have compromised the 'authenticity' of its historic fabric (ICOMOS 1996: 30). UNESCO's re-appraisal of the property eleven years later observed the 1994 Nara declaration's assertion that authenticity should not be judged on fixed criteria but within the cultural context that a site belongs (ICOMOS 1994). Accordingly, Carcassonne's inscription in 1997 portrayed the city's restoration (which played an iconic role in the emerging European heritage movement: see Ashworth and Howard 1999: 38) somewhat differently. Rather than compromising the site's historic integrity, the massive restorations were viewed as another distinctive layer to its cultural stratigraphy - a case of the heritage industry itself becoming heritage.

\section{Inclusion and Exclusion}

The management of city walls as heritage sites poses particular challenges as they constitute uniquely 'civic' monuments, both in terms of their past histories and (very often) their present-day status. As much as walls originally encircled populations for reasons of defence, their roles as symbols of commercial advantage, individuality and separateness have been more enduring. The Renaissance scholar Leon Battista Alberti considered a city without a wall 'naked' (Alberti 1986: 72): city defences have always defined their communities in an iconic as well as a physical sense. But, while historically city walls might be thought of as unambiguous markers of the urban limits, defining where the countryside stopped and the townscape started, this appearance can be illusory. City gates represent not simply barriers but transitional spaces between different spheres, within and without (for example, see Ratté 1999 on the gates of Florence and Siena). The urban edge was not a line marked rigidly in stone but a liminal zone of the townscape characterised by specific social or ethnic groups, activities and architecture (Creighton and Higham 2005: 32-50). The critical point here is that urban walls divided as well as united communities (and in many cases continue to do so), serving to create or exacerbate fractured identities. In these senses, while the image of the walled city might be outwardly be one of enclosure, cohesion and privilege, equally important but underestimated is the enduring role of walled heritage in excluding as well as embracing populations and in mediation with the world beyond the urban area.

The walls of Derry/Londonderry (not a WHS) are the very embodiment of the notion of city defences as an arena for contestation. In this 
case it is not the physical fabric of the walls that is disputed so much as rituals associated with the celebration of their martial past- in particular resistance to the siege of 1689 - as an expression of the heritage of Unionism (see MacGiolla Chriost 1886; Kelly 2001). In the late twentieth and early twenty-first century, this heritage is not only commemorated through the annual march around the (still Londonowned) walls but also contestedthrough challenges to the route of the parade and ultimately in the courts of Northem Ireland over the name of the city.

The potentially divisive consequences of walled heritage as a symbol of partition are again exemplified by Jerusalem (Figure 4). In the wake of the city's occupation in the 1967 Arab-Israeli war, former Israeli Prime Minister David Ben-Gurion advocated the dismantling of the walls to eradicate the long-standing division they embodied (Abu El-Haj 2002: 178-9). Walls could be attacked as symbols of a squalid or unpopular antique heritage well into the twentieth century. For example, large sections of the monumental clay walls of the desert city of Sana'a were dismantled by the local population in the immediate aftermath of the 1962 Yemeni revolution. The destruction symbolised a break with the authority and isolation of the previous Imamic regime and, in the voice of one resident, served to break the 'handcuffs' of the past (Al-Sallal 2004: 99). Within a generation, UNESCO's development plan for the WHS included the reconstitution of its walls (Lewcock 1986: 116). Yet a salutary lesson of the dangers of oversimplifying urban society's attitudes to walled heritage is provided by the complexity of local reactions after the dismantling of the Berlin Wall in 1989, which included 'wall nostalgia' (in East as well as West Berlin) in recognition of its lost benefits (Baker 1993: 730-1). Attitudes to walled heritage can also turn full circle in remarkably short periods of time. The WHS of Beijing's Forbidden City represents the focal point of the former walled Imperial City, which was until the 1950 s the world's largest and best preserved historic walled community, comprising a hierarchical arrangement of vast inner and outer circuits around the imperial palace (ICOMOS 1986). But while virtually the entire walled ensemble wastorn down as a statesponsored eradication of an evocative symbol of the 'Old China' within little more than a decade, the twenty-first century is witnessing the rebuilding and restoration of parts of the demolished circuits (and even their incorporation within branded heritage parks) in advance of the 2008 Olympic Games (see Shatzman Steinhardt 2000: 422; Chang and Halliday 2005: 542).

While the heritage industry might portray walled towns as unified celebrations of national heritage, the histories of these places frequently demonstrate division within society. Many circuits were built not as genuine communal enterprises but to control populations in some way. This is true, for instance, of many walled heritage towns planted as appendages to castles, as with Edward I's bastides 
in North Wales. In a very different cultural context, while in traditional Islamic history walled cities are frequently portrayed as lying on frontier zones - in particular between Islamic lands (dār alIslam) and non-Islamic territories (dār al-harb) - the individual histories of these places frequently confirm walling against internal threats within society (Bloom 2000: 221). Indeed, in the case of many Islamic walled cities the notion of a historic single 'corporate identity' is often false. We might even question whether their portrayal by the heritageindustry as unified entities is entirely appropriate considering that, historically, medieval Islamic urban places tended to lack the corporate institutions and self-identities of those in the Christian West, the major walled cities being rather collections of composite units (Lassner 2000: 123-30). The intramural gates and walls that defined these historic quarters were critical to a sense of place that may be lost through intervention and their removal in the face of development, as the cases of Tunis and Cairo exemplify (see Akbar 1988: 165-72).

Typically located on the edges of, or immediately beyond, enclosed zones, Jewish quarters represent another potentially contestable aspect of the heritage of walled cities (Ashworth 1997; see also Silberman 2005: 96-7). The Jewish heritage of a city such as Cordoba, where La Juderia quarter - clustered characteristically in the shadow of the city walls - symbolises a population dispossessed in the fifteenth century, is relatively uncontroversial (Cáceres, Évora and Provins are comparable cases of walled towns preserving tangible Jewish quarters), but other cases are less so. For example, a condition of the inscription of Sana'a as a WHS in 1986 was that the Jewish quarter tucked into the south-west part of the city walls and initially excluded from the proposal was encompassed within the designated zone, the city walls otherwise enclosing a sacred space with an exceptionally high density of mosques and recognised as a key centre for the spread of Islam from the seventh century (ICOMOS 1985b: 3). Bardejov was similarly inscribed with the recommendation that the designated area focused on the walled city was expanded to embrace the small Jewish district, including synagogue and baths (mitve), outside the fifteenth-century walls (ICOMOS 2000: 133). Issues of dissonance come into sharper focus in such Central and Eastern European WHS cities, due to the twentieth-century history of their Jewish communities and the incongruity of the near total absence of this social group from places that preserve a distinctive Jewish built heritage. The heritage of Cracow embodies dissonance of another level. Here, the Jewish Kazimierz district, located beyond the core and recognised from the fifteenth century as a legally separate entity with its own walls (now largely demolished), had by the end of the twentieth century transformed through 'Schindler Tourism' into a 'memorialised ghetto', the place's identity in the eyes of a massive transient tourist population having little resonance with the host community (Ashworth 2002: 366-7). 
Notwithstanding their enduring symbolic significance, town walls also represent undeniably martial pasts. They have been characterised as representing a branch of 'atrocity' heritage (Tunbridge and Ashworth 1996: 115-6), where episodes of violence and bloodshed featuring prominently in local social memory can force populations (and tourists) to negotiate an uncomfortable past. Many walled cities on the WHS list are border towns and have changed political or national allegiance in the past: Caernarfon/Caernarvon and Mazagan/El Jadida are two of many examples where alternative names betray a colonial heritage that is contestable. Other WHS walled cities have been contested in the martial sense of the word since inscription, the most recent case being the medieval towers at Byblos damaged as an (indirect) result of Israeli aerial bombing in 2006. Other walled WHS cities have been targeted specifically because WHS status identifies them as perceived symbols of national heritage, as with the shelling of Dubrovnik in 1991-2. While the material and human damage wrought within the walled area was inconsequential relative to the suburbs, it was the plight of the iconic walled 'Old City' and WHS that caught the world's eye (Larkham 1994: 263-4). If the military targeting of the sixteenth-century walled city of Mostar in 1992-5 was a 'political act', then so too was its inscription as a WHS in 2005 as an emblem of reconciliation. The WHS was designated as an historic ensemble centred on the Ottoman Stari Most bridge, rebuilt almost in its entirety with UNESCO and World Bank funding, even if the focal monument could not meet any conventional criteria of authenticity (Grodach 2002; Jokilehto 2006: 10).

\section{Delineation of Walled Heritage}

The walled towns depicted on Figure 1 embrace an enormous range of origins, sizes and plan forms (for typology, see Hopkinson 2000: 55-62). At Siena, seven kilometres of extant walls originally pierced by 36 gates define the heart of a thriving modern city. In sharp contrast are small 'time-frozen' townscapes such as Caernarfon and Urbino, where stunted urban growth has preserved what are essentially fossilised urban ensembles, circled in stone. These communities have divergent histories in terms of their attitudes towards walled heritage through episodes of disrepair and disinterest through to conservation and sometimes reconstruction. What unites them, however, is that, as monuments, city walls have biographies that are cyclical in some way: originally constructed as iconic monuments to urban identity, most walls have undergone episodes of degradation, before re-emerging as cherished symbols of civic prestige and vitality in the context of the heritage industry. Frequently, the lines of walls - whether extant or fossilised in the townscape in some way- mark the boundaries of designated WHS zones, although variations are apparent (for instance, eighteenthand nineteenth-century extra-mural settlements are encompassed at 
Riga). What is important here is that decisions regarding the delineation of walled cities as World Heritage Sites by definition embrace certain periods of the past and reject others. Prioritisation of the past can also be reflected in the 'branded' titles of inscribed sites - the 'Roman walls of Lugo' and 'Islamic Cairo' being clear cases in point, despite the multi-phase nature of the urban ensembles in question.

The concept of the 'buffer zone' (a protected envelope of surrounding space that is mandatory for WHS inscription: UNESCO 2005: 25-6) has particular importance in the case of walled towns. Effective conservation policies within buffer zones are essential to control the scale of extra-mural development and preserve the relationship between walled city and setting. Views of walled towns from outside can be important to the image of a city as heritage site: at Gjirokastra, San Gimignano and Sana'a, for example, in sharply contrasting cultural contexts it is the intensity of historic towered development within a tightly constrained (walled) area that defines the urban image. Shibam's remarkable early Islamic townscape was inscribed with the recommendation that the zone of protection was extended into the surrounding valley of the Wadi Hadramawt, with its concentration of pre-Islamic archaeological sites (ICOMOS 1981: 2). Similarly, at Ávila the original proposal was amended so that the WHS extended to embrace Romanesque churches and their associated squares that formed a distinctive extra-mural setting characteristic of the region (ICOMOS 1985a). Elsewhere, sites such as Acre, Lyons, Jerusalem and Urbino were inscribed on condition that more effective extra-mural buffer zones were included. Designated WHS zones also need not remain static. The area of Rome initially included in the 1980 bid (coinciding with the Aurelian city wall) was rejected as it ignored the medieval urban enceinte, and was consequently extended to embrace the wall of Urban VIII, only to be expanded further in 1990 to include additional extra-mural properties (ICOMOS 1990). WHS zones can also be extended as knowledge of the archaeological potential of their immediate environs increases, as at Dubrovnik and Butrint, where archaeological investigation revealed urban remains extending far beyond the walls, so that the area redesignated in 1999 included a substantial extra-mural area (Bowden et al. 2004).

\section{Conservation and Contestafion}

Effective management of this heritage of course recognises that town walls are indivisible from the townscapes within which they are embedded. Yet a long-standing tension exists between the restrictive qualities of walls and gates (and their conservation within the branded 'heritage city'), and the dynamic forces of urban change, which can exacerbate issues of dissonance (see Tunbridge and Ashworth 1996: 27-34). In certain contexts, uncontrolled 
development endangers the integrity of inscribed walled cities: at Shibam and Zabid, it is transforming living heritage into 'dying monuments' (Cernea 2001: 31), resulting in the inscription of the latter on to the list of World Heritage Sites in danger in 2000. Equally extreme is the clash with modernity experienced by many walled WHS medina towns in the Maghrib of North Africa (including Marrakesh, Sousse and Tétouan). Here 'traditional' settlements of narrow roads behind city walls can face massive challenges of deprivation and overcrowding, and tensions between the (potentially conflicting) imperatives of urban revitalisation and heritage conservation can be all too obvious. Many are 'polynuclear' cities (including the archetypal medina city of Fez), where the dichotomy between walled medinas and their accompanying colonial centres between colonizer and colonized - highlights another dimension to this dissonance (Slyomovics 2001: 1-5; see also Rghei and Nelson 1994: 143). In a very different context, the time-frozen tendency of the classic European 'gem city' (see Ashworth and Tunbridge 1990: 2) carries the risk of a heritage that is dissonant in a contrasting way. The image of the walled town frozen in time is given official recognition in UNESCO's inscription of the 'Museum City of Gjirokastra', for example, and exemplified by places such as Quedlinburg and Urbino. At worst, the nurturing of walled enclaves as branded heritage quarters can transform local communities into incidental players on 'stage sets' where heritage is commodified for economic exchange - a criticism levelled at the World Heritage Sites of Brugge and Carcassonne, for example (see Graham 2002: 1007).

As physically massive forms of material culture comprising long, sinuous (and often discontinuous) monuments whose precise ownership is frequently debatable, issues of protection and conservation can be unusually complex for town walls. Moreover, as monuments closely connected to the self-images of communities and sometimes referencing contested periods of the past, so their presentation and interpretation throws up philosophical and ideological questions. This is particularly the case where the physical fabric of city walls exhibits a tangibly multi-layered history, and treatment can neverbe entirely neutral. For example, it has been contended that the selective preservation and presentation of defensive walls in Jerusalem's Jewish Quarter emphasises the Israelite past, as in the 'Israelite Tower', where heritage displays fashion a history of sieges and threatened national destruction (Abu El-Haj 1998: 178; 2002: 208-9). The city's extant ramparts essentially date to the sixteenth century, being attributable to Sultan Suleiman the Magnificent, but their intangible heritage is multilayered and mutable (see Asali 1997: 201; Boas 1999: 13-21). The state-sanctioned destruction, by the Israeli military in 1967, of structures within the 'Maghariba Quarter' to create a plaza at the base of the Herodian blocks of the Western Wall shows how widely perspectives of 'host' communities can differ. While from one 
perspective these actions afforded a sacred monument 'breathing space' and a less cluttered physical setting, from another it removed not only an essential part of the Western Wall's sense of place but also a Muslim residential area whose social memory extended back to the twelfth century (Abu El-Haj 2002: 164-6; Dumper 2002: 78-80).

Populations need not always feel affinity with the walled heritage that surrounds them. While the present walls of the Old City of Acre represent an eighteenth-century Turkish construction (Pringle 1995: 81-4), the built environment of the Ottoman settlement overlies a walled Crusader-period city currently being investigated by the Israel Antiquities Authority (Boas 1999: 32-42; Stem 2000). Here, issues of dissonance are bought into sharp focus because of the 'placeless' nature of the present-day community, which comprises Palestinian migrants of the post-1948 period with little cultural attachment to the city. Continuous urban development frequently ensures that city walls become enmeshed in the living fabric of cities. At Zamość, inscription was conditional upon the adoption of a policy that would ensure demolition of 'unsympathetic' structures within the designated buffer zone (ICOMOS 1989: 2). But a blurred distinction exists between the judicious removal of structures encumbering or obscuring monumental remains to reveal and display the most historically valuable fabric, and a sanitisation of walled heritage that eradicates the contribution of communities themselves to the urban palimpsest. The epitome of the latter possibility is Carcassonne (Figure 3), where Viollet-le-Duc's restorations of the second half of the nineteenth century extended beyond the reconstruction of medieval fabric to remove over one hundred vernacular buildings and homes of textile workers clustered in the 'quartier des lices', between the inner and outer city walls (Amiel 200: 11-12). In a late twentiethcentury context, the population of Old Bagan, Burma's 'city of pagodas' was transplanted beyond a newly designated heritage zone by the military junta in the early 1990s, ostensibly to facilitate archaeological excavation but undoubtedly for heritage tourism, and the site has been refused admission to the WHS list (Taylor and Altenburg 2006: 278-80).

It goes without saying that such actions can cause a long-term dislocation between communities and their historic environment. The late thirteenth-century town wall of Conwy (Figure 5) is partly the product of mid twentieth-century 'conservation' that extended far beyond the treatment of masonry to include the reconstitution of part of a bank and ditch and the removal of structures built against it (Taylor 1995). While such actions might 'improve' the view of the site for external appreciation, they can also exacerbate the dissonant heritage of an unambiguously English monument in a present-day Welsh context, as the features removed arguably represented part of the community's own contribution to the town's identity, including industrial and nineteenth-century vernacular buildings (Austin 1997). 
In other cases, removal of structures built against city walls has continued after WHS inscription, as at Tarragona and Lugo, Spanish walled towns whose officially recognised historic 'value' relates primarily to their Roman heritage despite longer-term urban continuity. At the former archaeological research strategies nurtured by the municipality have focused on Roman buildings at the expense of modern infrastructure and renovations have seen parts of the medieval inner city pulled down; at the latter, the Gallician government is pursuing a policy of the systematic clearance of houses built against the Roman wall (van de Aa 2005: 123-4). A more worrying case is that of Bosra where, until recently, the Classical period runs housed a 'squatter-type' community that while ignored or written out of guidebooks - was a component of the site's sense of place since the eighteenth century. While the WHS inscription report noted that excavation and 'reclamation' was endangering the community's existence, 2001 saw the expulsion of the population (ICOMOS 1980: 2; Rowney 2004: 61-2).

\section{Conclusions}

Central to this paper have been the twin questions of how urban identities are shaped by walled heritage and how walled heritageis used, consciously or unconsciously, in the fashioning of identities. For the purposes of the international heritage industry city walls essentially define a product, and organisations such as the Organization of World Heritage Cities and the Walled Towns Friendship Circle are accordingly recognising the value of walled urban communities as among the world's foremost heritage tourism assets. But frequently, it seems, walls are a cloak concealing identities that are fractured rather than cohesive, and the arguments presented here can be equally applicable to walled communities not inscribed on the UNESCO list. The 'enclave heritage' of dispossessed groups, the layered identities of walls and their often very tangible references to disputed periods of the past, and their complex interrelationship with the built environment all create extraordinarily complex philosophical challenges for heritage management. The meanings of city walls and the identities they represent are not passive but active, and have inherent potential to be written and re-written through their treatment and presentation as heritage. No matter how sensitive the actions of agencies responsible for the fabric of monuments, neutral handling city walls which are the very embodiment of 'living' heritage is simply impossible, and many of the case studies examined here expose the difficulties of converting into practice the principle of the 1994 Nara Declaration that "The cultural heritage of each is the cultural heritage of all". 
University of Exeter

\section{References}

Abu El-Haj, N.L. 1998. Translating truths: nationalism, the practice of archaeology, and the remaking of past and present in contemporary Jerusalem. American Ethnologist, 25.2: 166-188.

Abu El-Haj, N.L. 2002. Facts on the Ground: archaeological practice and territorial selffashioning in Israeli society. Chicago: University of Chicago Press.

Akbar, J. 1988. Crisis in the Built Environment: The Case of the Muslim City. London: Routledge.

Alberti, L.B. 1986. Ten Books on Architecture, Translated into English by James Leoni. New York: Dover Publications.

Al-sallal, K.A. 2004. Sana'a: Transformation of the Old City and the Impacts of the Modern Era. In Planning Middle Eastern Cities: An Urban Kaleidoscope in a Globalizing World (ed. Y. Elsheshtawy). London: Routledge, pp. 85-113.

Amiel, C. 2000. De la place forte au Monument. La restauration de la cité de Carcassonne au XIXe siècle. Paris: Éditions du Patrimoine.

Asali, K.J. 1997. Jerusalem under the Ottomans, 1516-1831. In Jerusalem in History: 3000BC to the present day. London: Kegan Paul, 200-227.

Ashworth, G.J. 1997. Jewish culture and holocaust tourism. Culture and Tourism (ed. M. Robinson). Newcastle: Centre for Tourism Studies.

Ashworth, G.J. 2002. Holocaust tourism: the experience of KrakówKazimierz. International Research in Geographical and Environmental Education, 11.4: 363-367.

Ashworth, G.J. and Howard, P. 1999. European Heritage Planning and Management. Exeter: Intellect.

Ashworth, G.J. \& Tunbridge, J.E. 1990. The Tourist-Historic City: Retrospect and Prospect of Managing the Heritage City. London: Belhaven.

Austin, D. 1997. Devolution, castles and Welsh identity. British Archaeology, 29.

Baker, F. 1993. The Berlin Wall: production, preservation and consumption of a 20th-century monument. Antiquity 67: 709-733.

Bloom, J.M. 2000. Walled cities in Islamic North Africa and Egypt with particular reference to the Fatamids (909-1171). In City Walls: the urban 
enceinte in global perspective (ed. J.D. Tracy). Cambridge: Cambridge University Press, 219-246.

Boas, A.J. 1999. Crusader Archaeology: The Material Culture of the Latin East. London: Routledge.

Bowden, W., Hodges, R. \& Lako, K. 2004. Byzantine Butrint: Excavations and Surveys 1994-1999. Oxford: Oxbow Books.

Bruce, D. and Creighton, O.H. 2006. Contested identities: the dissonant heritage of European town walls and walled towns. International Journal of Heritage Studies, 12.3: 234-254.

Cernea, M.M. 2001. Cultural Heritage and Development: a framework for action in the Middle East and North Africa. Washington: World Bank.

Chang, J. and Halliday, J. 2005. Mao, The Unknown Story. London: Jonathan Cape.

Creighton, O.H. and Higham, R.A. 2005. Town Walls: a social history and archaeology of urban defence. Stroud: Tempus.

Dumper, M.R.T. 2002. The Politics of Sacred Space: the Old City of Jerusalem in the Middle East conflict. London: Lynne Rienner.

Evans, G. 2002. Living in a world heritage city: stakeholders in the dialectic of the universal and particular. International Journal of Heritage Studies, 8.2: 117-135.

Graham, B. 2002. Heritage as knowledge: capital or culture. Urban Studies 39: 1003-

Grodach, C. 2002. Reconstituting identity and history in post-war Mostar, Bosnia-Herzegovina. City: Analysis of Urban Trends, Culture, Theory, Policy, Action 6.1: 61-82.

Hopkinson, M.F. 2000. Living in defended spaces: past structures and present landscapes. Landscapes, 1.2: 53-77.

ICOMOS 1980. World Heritage Evaluation Report Number 22, The Old City of Bosra. UNESCO.

ICOMOS 1981. World Heritage Evaluation Report Number 192, The Old walled City of Shibam. UNESCO.

ICOMOS 1985a. World Heritage Evaluation Report Number 348 Rev., City of Ávila with its Extra Muros Churches. UNESCO.

ICOMOS 1985b. World Heritage Evaluation Report Number 385, Old City of Sana'a, Arab Republic of Yemen. UNESCO. 
ICOMOS 1986. The Imperial Palace of the Ming and Qing Dynasties. UNESCO.

ICOMOS 1989. World Heritage Evaluation Report Number 564, The Old Town of Zamość. UNESCO.

ICOMOS 1990. World Heritage Evaluation Report Number 91bis, Rome. UNESCO.

ICOMOS 1994. The Nara Document on Authenticity. UNESCO.

ICOMOS 1996 World Heritage Evaluation Report Number 345 rev, Carcassonne, France. UNESCO.

ICOMOS 2000. World Heritage Evaluation Report Number 973, Bardejov, Slovakia. UNESCO.

Jokilehto, J. 2006. Considerations on authenticity and integrity in World Heritage context. City and Time 2.1: 1-16.

Kelly, W. 2001. The Sieges of Derry. Dublin: Four Courts Press.

Klein, M. 2001. The Contested City. London: Hurst.

Larkham, P.J. 1994. A new heritage for a new Europe. In Building a New Heritage: tourism, culture, and identity in the new Europe (eds G.J. Ashworth and P.J. Larkham). London: Routledge, pp. 260-273.

Lassner, G. 2000. The Middle East Remembered: forged identities, competing narratives, contested spaces. Ann Arbor: University of Michigan Press.

Lewcock, R. 1986. The Old Walled City of Sana'a. Paris: UNESCO.

MacGiolla Chriost, D. 1996. Northem Ireland: culture clash and archaeology. In Nationalism and Archaeology (eds J.A. Atkinson, I. Banks and J. O'Sullivan). Glasgow: Cruithne Press, 128-134.

Perbellini, G. (ed.) 2000. The Town Walls in the Middle Ages: les enceintes urbaines au moyen age. The Hague: Europa Nostra IBI Bulletin No. 53.

Pringle, D. 1995. Town defences in the Crusader kingdom of Jerusalem. In Fortification and Settlement in Crusader Palestine (ed. D. Pringle). Ashgate: Variorum, pp. 69-121.

Ratté, F. 1999. Architectural invitations: images of city gates in medieval Italian painting. Gesta, 38.2: 142-153. 
Rghei, A.S. and Nelson, J.G. 1994. The conservation and use of the walled city of Tripoli. The Geographical Journal, 160: 143-158.

Rowney, B. 2004. Charters and the Ethics of Conservation: A CrossCultural Perspective. Doctoral dissertation. University of Adelaide.

Shatzman Steinhardt, N. 2000. Representations of Chinese walled cities in the pictorial and graphical arts. In City Walls: the urban enceinte in global perspective (ed. J.D. Tracy). Cambridge: Cambridge University Press, 419460.

Silberman, N. 2005. Jewish and Muslim Heritage in Europe: the role of archaeology in defending cultural diversity. Museum International, 57.3: 95-100.

Slyomovics, S. (ed.) 2001. The Walled Arab City in Literature, Architecture and History: the city medina in the Magrhib. London and Portland: Frank Cass.

Stern E. 2000. The center of the Hospitaller order in Akko. Qadmoniot, 119: 4-12.

Taylor, A.J. 1995. The town and castle ofConwy: preservation and interpretation. Antiquaries Journal, 75: 339-363.

Taylor, K. and Altenburg, K. 2006. Cultural landscapes in Asia-Pacific: potential for filling world heritage gaps. International Journal of Heritage Studies, 12.3: 267-282.

Tracy, J.D. (ed.) 2000. City Walls: The Urban Enceinte in Global Perspective. Cambridge: Cambridge University Press.

Tunbridge J.E. and Ashworth G. 1996. Dissonant Heritage: managing the past as a resource in conflict. Chichester John Wiley and Sons.

UNESCO 1981. Convention Concerning The Protection Of The World Cultural And Natural Heritage, World Heritage Committee First Extraordinary Session, Paris, 10 and 11 September 1981. UNESCO.

UNESCO 2005. Operational Guidelines for the Implementation of the World Heritage Convention. UNESCO.

van $\operatorname{der}$ Aa, B. 2005. Preserving the Heritage of Humanity? Obtaining world heritage status and the impacts of listing. Doctoral dissertation. University of Gronigen.

Oliver Creighton is Senior Lecturer in Archaeology at the University of Exeter. Specialising in the study of medieval buildings, landscapes 
and townscapes, he has a particular interest in the archaeology of status and authority. His recent books include Medieval Town Walls: $A$ Social History and Archaeology of Urban Defence (2005) and Castles and Landscapes: Power, Community and Fortification in Medieval England (2005).

\section{List of Figures}

Figure 1. Walled towns and cities inscribed as World Heritage Sites in Europe, North Africa and the Middle East. Cities are labelled alongside the year of their inscription on to the UNESCO World Heritage Site List.

Figure 2. Plans and topographies of selected walled cities on the UNESCO World Heritage Site list.

Figure 3. The walled city of Carcassonne, showing 'les lices' - the zone between the inner and outer city walls cleared of occupation during restoration in the nineteenth and early twentieth century (photograph: O. Creighton).

Figure 4. The city walls of Jerusalem. Outwardly dating to the sixteenth century but following much the same line as an earlier circuit, the walls have a particularly complex and multi-layered identity (photograph: T. Barry).

Figure 5. The town walls of Conwy. In several areas immediately outside the walls 'encumbering' structures were removed and a town ditch reconstituted in the 1950s and 60s (photograph: O. Creighton). 